\title{
Review of Alison MacKenzie, Jennifer Rose, and Ibrar Bhatt (Eds.). (2021). The Epistemology of Deceit in a Postdigital Era: Dupery by Design
}

\section{Cham: Springer. 312 pp. ISBN 9783030721534(Hardcover)}

\section{Mats Hyvönen ${ }^{1}$}

Accepted: 11 October 2021 / Published online: 2 November 2021

(c) The Author(s), under exclusive licence to Springer Nature Switzerland AG 2021

Keywords Dupery by design · Epistemology $\cdot$ Deceit $\cdot$ Postdigital $\cdot$ Fake news · Post-truth $\cdot$ Social media $\cdot$ Higher education

\section{Introduction}

Fake news, in the sense of deliberate mis- and disinformation, is nothing new. While today it is typically associated with Trump and Brexit-or conspiracy theories such as Pizzagate ${ }^{1}$ - fake news has an extensive history. For as long as humans have engaged in mediated communication, satire and parody as well as entirely fabricated content have been part of public discourse. The motives for creating and disseminating misleading information have varied from the wish to entertain to the intention to deceive, and throughout history, the effects of fake news have ranged from amusement to death (Burkhardt 2017: 5). One might doubt the utility of a buzzword such as 'fake news', but the phenomena indicated by the term nonetheless constitute a serious challenge to any notion of the 'public sphere' as the space in which commonality is established and maintained (cf. Arendt 1958: 52).

Much of the research on fake news has been published after 2016, when 'posttruth' was chosen as Oxford Dictionaries' Word of the Year (Oxford Languagues 2016). It focuses largely on fake news as a contemporary phenomenon linked to populist political movements, and in many of these accounts, fake news is presented

\footnotetext{
1 'Pizzagate' is a thoroughly debunked conspiracy theory that went viral during the 2016 US presidential election. It claims that prominent members of the Democratic Party are involved in global human trafficking and sexually abusing children in satanic rituals in the basement of the Washington D.C. pizzeria Comet Ping Pong (Samuelson 2016).
}

Mats Hyvönen

mats.hyvonen@antro.uu.se

1 Uppsala University, Uppsala, Sweden 
as posing a threat to objectivity, and, ultimately, to liberal democracy. The standard approach is to examine who is misleading whom about what, in which way, and for what reason. But the deepest issue with regard to our political institutions and the public sphere is not that there are actors bending or breaking implicit or explicit rules of good publicistic conduct. Rather, it is that the rules themselves are being contested and renegotiated. From a historical perspective, post-truth and fake news can be seen as the contemporary manifestation of the age-old struggle over who decides the conceptual framework for making and adjudicating between truth claims (Fuller 2018: 185). However, the radical transformations after the digital revolution demand new ways of thinking about the public, not only about politics and democracy, but also about education and research.

The Epistemology of Deceit in a Postdigital Era: Dupery by Design (MacKenzie et al. 2021) takes as its starting point the 'messy' (Jandrić et al. 2018) concept of the postdigital. The 15 contributions, in different ways, testify to the fact that it can be a very productive concept for thinking through the consequences of the technological and political transformations that have occurred in the past few decades. Overall, the true merit of the book lies in that it addresses the problems of fake news, conspiracy thinking, and other disturbing phenomena in the postdigital not just by highlighting the complexity and entanglement (the 'messiness') of digitality in contemporary human existence, but by taking the bull by the horns and addressing it directly.

Like many other books on the current situation, Epistemology of Deceit in a Postdigital Era: Dupery by Design is a reflection of the four years of Trump's presidency and the Brexit referendum. However, unlike most other books on the subject, it is an act of resistance: each contribution proposes how to counter and resist deception and dupery. While the chapters in many different ways deepen our understanding of the problems, challenges, and dangers of our postdigital times (such as dupery by design, i.e., that deception may be built into the platforms and structures around us, lurking in everything from technology to language), they also call for action. There are things that we-as educators, researchers, and citizens_- can and perhaps must do.

\section{Epistemology of Deceit}

The first of the four parts of the book is concerned 'with the threats to democratic processes posed by deceit, engagement in bad faith politics, and the rejection of the intrinsic value of truth' (MacKenzie et al. 2021: xx).

The opening chapter asks the question: maybe democratic governments could employ deceit as a way of protecting themselves? MacKenzie and Bhatt's answer is that since 'ethical conduct, such as truth-telling, is critical to democracy and positive human relations' (2021: 17), divorcing politics from ethics is never an option. At the same time, they remind us we have to be realistic. There will always be people with cynical views of human nature and thus prone to Machiavellian behavior. Still, restricting free speech is not the way to go because "we need to enable people to be exposed to differing perspectives and to engage substantively across existing social divides' (17). Combating conspiracy theories (and other hoaxes) requires genuine but critical engagement with the ideas and the people who advocate them. 
Truth is important, but it is essential that we reflect on the conditions under which we arrive at the conclusion that something is true. In her contribution, Jennifer Rose concludes that although truth should remain an epistemic aim, it should always be accompanied by the understanding that 'holistically, we do not possess epistemic certainty' (Rose 2021: 30). Rose constructs an 'epistemology of false beliefs' to show one way in which audiences acquire false beliefs. By focusing on the relationship between truth, trust, and technology, she highlights the social character of information and knowledge. We depend on trust, and have to trust others, to tell the truth. Insisting on truth being the sole epistemic aim opens for exploitation of the certainty in one's trusted relationships. What is needed in today's online life is a healthy skepticism about our truth claims and beliefs about truth. Education is key, since it can 'help people understand the limits to what they know, the certainty of what they know, and what they can reasonably know, not only in online environments but also through any technologically mediated communication' (35).

One of the most difficult challenges today is that some very influential debaters just do not care if what they say is true or not. In the final chapter of part 1, Jake Wright analyzes epistemic nihilism - 'the rejection of truth as an intrinsic or instrumental good' (Wright 2021: 41) — and how to respond to it. Epistemic nihilism is a form of cheating: while their interlocutors often are concerned with the truth, the nihilists themselves are not. The danger is that people might accept the nihilists' genuinely dangerous claims (for instance, that injecting bleach will cure COVID-19²). Wright asserts that employing strategies within established norms, such as fact-checking, flagging, or removal of posts on Facebook or Twitter, is just not enough to combat the harmful effects of, for example, serial lying. In extreme cases, Wright concludes, 'we ought to simply deny the nihilist a platform from which to speak' (41). What exactly constitutes an 'extreme' case leaves further questions to be answered, but these strict measures would certainly be reserved for very influential serial offenders.

\section{Dupery, Politics, and Democracy}

The second part of the book gathers four chapters which "examine the impact and consequences of dupery, fake news, and information disorders on democracy, liberal democratic institutions, human rights, and the invisibility of animal welfare' (MacKenzie et al. 2021: xxi).

In her contribution, Tess Maginess focuses on how dupery infects and weaponizes language, resulting in a degradation observable in how certain words (most notably, 'radical' and 'liberal') have taken on negative connotations for some people and have become terms of contempt and abuse rather than progress and inclusion. The degradation of language is, in turn, a condition for the populists to appear like 'ordinary people' as opposed to the 'plush skinned elite, shimmering in you-will-not-understand theory'

\footnotetext{
${ }^{2}$ In the spring of 2020, the US President Donald Trump was criticized by the medical community for suggesting research into whether coronavirus might be treated by injecting disinfectant into the body (BBC 2020).
} 
(Maginess 2021: 71). To resist these tendencies, solidarity needs to be created by 'listening to the voices of the oppressed and marginalized' (73). The 'engaged university' not adhering to neoliberal fashion or policies but instead involved in greater knowledge sharing and exchange between the global north and south plays an important part in this.

Another way to fight lies and deception is to take legal action against fake news. However tempting that might be for lawmakers, this has potentially severe complications. Drafting laws against falsehood and manipulation online presumes that the lawmakers can clearly discern between what is fake news and what is not. Taking Singapore as his case study, Özdan (2021: 88) warns that 'regulations or legal enforcements regarding digital platforms and textual or other content types on these platforms should not be drafted and adopted without taking account of international human rights law'. There is an imminent risk that attempts to legally counter mis- and disinformation will result in arbitrary laws which in the hands of the less scrupulous turn into tools of oppression of human rights, specifically the right to freedom of expression and opinion. Thus, rather than censorship, Özdan (2021: 92) argues for the need of 'concerted and thoroughgoing digital and media literacy programs, transparency policies, and independent, impartial, and fair supervisory boards'.

Surely, many of those who wish for legislation are thinking of Trump's serial lying and his diversion of the term 'fake news' into a propaganda tool. Trump himself, however, is not as important as the right-wing media ecosystem and its statesponsored disinformation. Benjamin Green's Habermasian critique of Trump's fake news approach to the first amendment focuses on how hyper-partisan rightist media, working in conjunction with the state, formed a bulwark of 'digital nationalism' which facilitated Trump's attacks on first amendment freedoms in relation to the 2020 Black Lives Matter protests. According to Green, what is needed, now and in the future, is a more robust resistance to this kind of threats to constitutional rights. His recommendation is that 'the Left adopt a unified discourse of reform which seeks to undergird longstanding First Amendment principles (validity) within procedurally defined (facticity) frameworks' (Green 2021: 112).

Sullivan (2021) shifts focus from humans and instead examines the consequences of fake news on animals. She uses the concept 'Anthropocentric noise disorder' to describe how the trauma of non-human animals is obscured by human interests. The problem is not only that the scarce information and public debate about exploitative human-animal relationships is, or could be, fake or false, but rather that it is missing, absent, and excluded altogether. A majority of the research on fake news is focused on that which appears to us in the positive such as published texts and recorded utterances. However, like mis- and disinformation, the practices of the invisibilization of animals, O'Sullivan argues, is also constitutive of untruthfulness.

\section{Discourse and Digital Literacy}

In Part 3, the contributors 'reveal how processes of discourse and practices of digital literacy are best understood as embedded in social and material networks, and incorporated into platform users' engagement with the world, rather than simply in terms of technologies and their "affordances" (MacKenzie et al. 2021: xxii). 
In the subtitle of her chapter, Saul (2021: 139) asks: 'Is there an obligation to correct false and oppressive speech on social media?' The short answer is no, or at least not on your own or without carefully thinking things through before taking action. She arrives at this conclusion by first engaging with the work of philosophers on counterspeech in general and then by turning to the specific issues posed by social media. The literature on counterspeech includes concerns not only about efficacy (i.e., that objecting to something in a certain situation will only make matters worse) but also of safety and power dynamics - that speaking up involves risks that might be too big to take on the 'epistemic obligation to voice disagreement' (140). These concerns are greatly magnified in the context of social media where, for instance, 'objecting to something is very likely to amplify it' (148) (emphasis from the original). Saul concludes that social media has brought new problems as well as new opportunities for counterspeech. In the postdigital context, however, we need to think carefully and strategically through how to correct false and oppressive speech, preferably by involving groups and institutions since it is unlikely that direct individual confrontation is the way to go.

In the postdigital era of problematic information, especially the kind that stems from broader social marginalizations, there is an ever-increasing need for critical media literacy that enables pedagogies that can work to battle such problematic information. By employing feminist new materialist theories of intra-action and lively assemblage, Jialei Jiang and Matthew A. Vetter examine Wikipedia's systemic biases. They do so by studying critical media literacy practices in the form of Wikipedia-based writing projects conducted by graduate and undergraduate students. Wikipedia-based assignments, Jiang and Vetter conclude, give students opportunities to practice critical media literacy and to 'write against the epistemology of deceit in the online encyclopedia' (Jiang and Vetter 2021: 173).

Shifting focus to neoliberal ideology, Albin Wagener examines the concept of 'market', central to understanding how today's societies function and the ways they exchange both goods and information. Our postdigital age, Wagener argues, is one of hypernarrativity in which truth has become a marketable concept and thus subject to market competition. Various expressions of truth emerge from mediated and manipulable discourses. 'Zombemes' are essential linguistic items that enable neoliberalism to present itself as nonideological and without an alternative. As Wagener (2021: 190) formulates it: '[N]eoliberalism uses zombemes to turn it into a form of quantum ideology: it appears to be absent, until you measure it.' Discourse analysis plays a central part in flushing out the zombemes and thereby decontaminating discourses in the postdigital society.

Memes, as visual rather than textual content, play a central role in today's digital world. According to Hajimichael (2021), that should make us concerned. The problem with memes is that even if they present themselves as a form of humor, they also feed into the current tendency to share the exaggerated and the fake. Hajimichael analyzes widely circulated, misinformative memes on refugees in the EU. The problem of memes in this context is that they distort, ridicule, and trivialize the hardships of real people. To counter the resulting demonizing and marginalization of life experiences, Hajimichael (2021) advocates for the use of critical discourse analysis and media literacy interventions to develop critical thinking in students. 


\section{Towards a Critical Pedagogy}

Part 4 of the collection comprises four chapters 'which connect education, technology, and deception to raise pedagogical questions about the goals and purposes of education, education structures, and uses of technology' (MacKenzie et al. 2021: xxii).

According to McLaren and Jandrić (2021: 216), 'the world is headed in the direction of a disaster so catastrophic that only dystopian novels or films have managed to calibrate the increasing scale of the horrors facing humanity'. The problem is the hegemonic hold of transnational capitalism (a key characteristic of the twenty-first century version of fascism) over the working class. This dire situation demands action and the authors argue for a specific form of critical pedagogy, namely scallywag pedagogy, which is 'a pedagogical counterforce that both understands the dangers of a post truth world that embraces conspiratorial right-wing "alternative facts" and abandons self-reflexivity and dialogue as a key means of democratizing our social universe' (216). To protect us from tomorrow's fascists, mandatory classes in media literacy situated in a revolutionary critical pedagogy are necessary at the universities. Only then can we start the necessary reconfiguring of human beings and technologies to transform the world beyond capitalism.

Taking a rather different, less revolutionary approach, Sinclair (2021) asks instead what we can learn from the deceptive practices of not only both benign dupers and deceivers such as magicians and educators teaching through deception, but also malicious deceivers such as hoaxers, hackers, and con artists. Sinclair concludes that dupery, both malicious and benign, usually depends on stories and that opportunities for deception arise when we are not aware of the genre and if we are distracted and not aware of the other stories in the same context. Teaching how dupery works may help protect us from it but there are ethical risks in such endeavors: we could be educating new generations of dupers and deceivers.

The digitalisation of the universities holds its own challenges. Ralston (2021) shows how online teaching opens for new ways of cheating while at the same time enjoying undue privileges relative to non-digital and pre-digital alternatives. At the neoliberal/corporate university, productivity outcomes such as graduation rates are valued over academic excellence resulting in managers and administrators pushing to normalize student ghosting (having someone else take your exams or complete your assignments). To counter both the cheating and the lip service of executives to academic integrity, Ralston suggests a postdigital strategy comprising both out-group actors (e.g., politicians) making demands that higher education institutions enforce their academic integrity policies as well as taking concrete action to verify the identity of students taking exams. To meet these postdigital challenges, universities need to incentivize ethical behavior but 'the dupery committed by institutional actors who seek to incentivize ... academic dishonesty' (Ralston 2021: 263) also needs to be exposed.

In the final chapter, Eamon Costello and Prajakta Girme adopt the methodology of social science fiction, a form of speculative fiction, to expose the deception 
embedded in datafication, i.e., 'the reduction of people to numbers, bytes and letters' (Costello and Girme 2021: 266). In their creative approach, the method is itself an act of resistance that allows for imagining better futures for higher education. By exploring education as posthuman practice, the authors challenge ingrained ideas of what a university is or could be. What we need is the ability to imagine a university beyond ideas and representations of them as sites of power and prestige.

\section{A Way Forward?}

The era when the mass media and professional journalists held a monopoly in the attention business is long gone. In today's thoroughly digitized existence where, with relatively inexpensive devices, anyone with a modicum of technical know-how can gather, formulate, and disseminate information, the flow of news, fake or not, is likely to broaden, deepen, and accelerate. The surge in fake news is largely the result of a democratization of the media environment insofar as many more people can engage in creating and disseminating content and reach and impact potentially very large audiences.

The problem, however, is not that people from almost all walks of life and almost regardless of where they live were given possibilities, unparalleled in history, to share their ideas and views with the world. It is rather the monopolization of those possibilities by a few global megacompanies that cause many of the problems we like to summarize in terms such as 'post-truth' and 'fake news'. It remains to be seen whether the ongoing developments will allow for a re-invention of the most important facet of the ideal-type 'public sphere', i.e., the idea that there are things about our shared world that everyone, no matter what their ideological bent, should be able to inform themselves about and participate in the debate about its future.

As of this writing, things are looking grim. The media (old and new, mass and social) seem to lack not only the requisite institutional capacity and authority, but also the ambition to shoulder the responsibility involved in being truly public in this respect. A further and perhaps even more menacing prospect is that, for similar reasons, there may be no other candidates in a position to take on the mantle (Hyvönen 2018; Rider 2020).

But it is not all doom and gloom. The contributors to The Epistemology of Deceit in a Postdigital Era: Dupery by Design (MacKenzie et al. 2021) address a multitude of approaches in detecting, understanding, and combating dupery online which make an excellent starting point for necessary future work. Hopefully this collection can inspire other scholars to critically engage with the acute problems and challenges of dupery and deceit.

\section{References}

Arendt, H. (1958). The human condition. Chicago, IL: University of Chicago Press.

BBC (2020). Coronavirus: Outcry after Trump suggests injecting disinfectant as treatment. BBC News, 24 April. https://www.bbc.com/news/world-us-canada-52407177. Accessed 10 October 2021. 
Burkhart, J. M. (2017). Combating Fake News in the Digital Age. Library Technology Reports, 53(8), $1-36$.

Costello, E., \& Girme, P. (2021). 'Choice Is Yours': Anatomy of a Lesson Plan from University V. In A. MacKenzie, I. Bhatt, \& J. Rose (Eds.), The Epistemology of Deceit in a Postdigital Era: Dupery by Design (pp. 265-281). Cham: Springer. https://doi.org/10.1007/978-3-030-72154-1_15.

Fuller, S. (2018). Post-Truth: Knowledge as A Power Game. London and New York: Anthem Press.

Green, B. (2021). US Digital Nationalism: A Habermasian Critical Discourse Analysis of Trump's 'Fake News' Approach to the First Amendment. In A. MacKenzie, J. Rose, \& I. Bhatt (Eds.), The Epistemology of Deceit in a Postdigital Era: Dupery by Design (pp. 95-117). Cham: Springer. https://doi. org/10.1007/978-3-030-72154-1_6.

Hajimichael, M. (2021). Social Memes and Depictions of Refugees in the EU: Challenging Irrationality and Misinformation with a Media Literacy Intervention. In A. MacKenzie, J. Rose, \& I. Bhatt (Eds.), The Epistemology of Deceit in a Postdigital Era: Dupery by Design (pp. 195-212). Cham: Springer. https://doi.org/10.1007/978-3-030-72154-1_11.

Hyvönen, M. (2018). As a Matter of Fact. Journalism and Scholarship in the Post-Truth Era. In M. A. Peters, S. Rider, M. Hyvönen \& Tina Besley (Eds.), Post-Truth, Fake News: Viral Modernity \& Higher Education (pp. 121-132). Cham: Springer. https://doi.org/10.1007/978-981-10-8013-5_10.

Jandrić, P., Knox, J., Besley, T., Ryberg, T., Suoranta, J., \& Hayes, S. (2018). Postdigital Science and Education. Educational Philosophy and Theory, 50(10), 893-899. https://doi.org/10.1080/00131857. 2018.1454000 .

Jiang, J., \& Vetter, M. A. (2021). Writing Against the 'Epistemology of Deceit' on Wikipedia: A Feminist New Materialist Perspective Towards Critical Media Literacy and Wikipedia-Based Education. In A. MacKenzie, J. Rose, \& I. Bhatt (Eds.), The Epistemology of Deceit in a Postdigital Era: Dupery by Design (pp. 159-176). Cham: Springer. https://doi.org/10.1007/978-3-030-72154-1_9.

MacKenzie, A., \& Bhatt, I. (2021). Bad Faith, Bad Politics, and Bad Consequences: The Epistemic Harms of Online Deceit. In A. MacKenzie, J. Rose, \& I. Bhatt (Eds.), The Epistemology of Deceit in a Postdigital Era: Dupery by Design (pp. 3-20). Cham: Springer. https://doi.org/10.1007/ 978-3-030-72154-1_1.

MacKenzie, A., Rose, J., \& Bhatt, I. (Eds.). (2021). The Epistemology of Deceit in a Postdigital Era: Dupery by Design. Cham: Springer.

Maginess, T. (2021). Duperation: Deliberate Lying in Postdigital, Postmodern Political Rhetoric. In A. MacKenzie, J. Rose, \& I. Bhatt (Eds.), The Epistemology of Deceit in a Postdigital Era: Dupery by Design (pp. 63-75). Cham: Springer. https://doi.org/10.1007/978-3-030-72154-1_4.

McLaren, P., \& Jandrić, P. (2021). Scallywag Pedagogy. In A. MacKenzie, I. Bhatt, \& J. Rose (Eds.), The Epistemology of Deceit in a Postdigital Era: Dupery by Design (pp. 215-232). Cham: Springer. https://doi.org/10.1007/978-3-030-72154-1_12.

O'Sullivan, V. (2021). A Project of Mourning: Attuning to the Impact of 'Anthropocentric-Noise Disorder' on Non-Human Kin. In A. MacKenzie, J. Rose, \& I. Bhatt (Eds.), The Epistemology of Deceit in a Postdigital Era: Dupery by Design (pp. 119-136). Cham: Springer. https://doi.org/10.1007/ 978-3-030-72154-1_7.

Oxford Languages. (2016). Word of the Year 2016. https://languages.oup.com/word-of-the-year/2016/. Accessed 10 October 2021.

Özdan, S. (2021). The Right to Freedom of Expression Versus Legal Actions Against Fake News: A Case Study of Singapore. In A. MacKenzie, J. Rose, \& I. Bhatt (Eds.), The Epistemology of Deceit in a Postdigital Era: Dupery by Design (pp. 77-94). Cham: Springer. https://doi.org/10.1007/ 978-3-030-72154-1_5.

Ralston, S. J. (2021). Ghosting Inside the Machine: Student Cheating, Online Education, and the Omertà of Institutional Liars. In A. MacKenzie, I. Bhatt, \& J. Rose (Eds.), The Epistemology of Deceit in a Postdigital Era: Dupery by Design (pp. 251-264). Cham: Springer. https://doi.org/10.1007/978-3030-72154-1_14.

Rider, S. (2020). Going Public: Higher Education and the Democratization of Knowledge. In M. A. Peters, T. Besley, P. Jandrić, \& X. Zhu (Eds.), Knowledge Socialism. The Rise of Peer Production: Collegiality, Collaboration, and Collective Intelligence (pp. 197-215). Singapore: Springer. https:// doi.org/10.1007/978-981-13-8126-3_10.

Rose, J. (2021). An Epistemology of False Beliefs: The Role of Truth, Trust, and Technology in Postdigital Deception. In A. MacKenzie, J. Rose, \& I. Bhatt (Eds.), The Epistemology of Deceit in a Postdigital Era: Dupery by Design (pp. 21-37). Cham: Springer. https://doi.org/10.1007/ 978-3-030-72154-1_2. 
Samuelson, K. (2016). What to Know About Pizzagate, the Fake News Story With Real Consequences. Time, 5 December. https://time.com/4590255/pizzagate-fake-news-what-to-know/. Accessed 10 October 2021.

Saul, J. (2021). Someone Is Wrong on the Internet: Is There an Obligation to Correct False and Oppressive Speech on Social Media? In A. MacKenzie, J. Rose, \& I. Bhatt (Eds.), The Epistemology of Deceit in a Postdigital Era: Dupery by Design (pp. 139-157). Cham: Springer. https://doi.org/10. 1007/978-3-030-72154-1_8.

Sinclair, C. (2021). Learning from the Dupers: Showing the Workings. In A. MacKenzie, I. Bhatt, \& J. Rose (Eds.), The Epistemology of Deceit in a Postdigital Era: Dupery by Design (pp. 233249). Cham: Springer. https://doi.org/10.1007/978-3-030-72154-1_13.

Wagener, A. (2021). The Neoliberal Colonization of Discourses: Gentrification, Discursive Markets and Zombemes. In A. MacKenzie, J. Rose, \& I. Bhatt (Eds.), The Epistemology of Deceit in a Postdigital Era: Dupery by Design (pp. 177-193). Cham: Springer. https://doi.org/10.1007/978-3-03072154-1_10.

Wright, J. (2021). Towards a Response to Epistemic Nihilism. In A. MacKenzie, J. Rose, \& I. Bhatt (Eds.), The Epistemology of Deceit in a Postdigital Era: Dupery by Design (pp. 39-59). Cham: Springer. https://doi.org/10.1007/978-3-030-72154-1_3.

Publisher's Note Springer Nature remains neutral with regard to jurisdictional claims in published maps and institutional affiliations. 